\title{
Pengaruh Pendekatan Matematika Realistik terhadap Pemahaman Konsep Matematika Siswa
}

\author{
Adrianus A. Jeheman', Bedilius Gunur², dan Silfanus Jelatu ${ }^{3 *}$ \\ 1,2,3*Program Studi Pendidikan Matematika, STKIP Santu Paulus, Indonesia \\ Jalan A. Yani No 10, Ruteng, Nusa Tenggara Timur, Indonesia \\ 1jehemanguy07@gmail.com,2Gbedilius@gmail.com, \\ 3*silfanusjelatu@yahoo.co.id
}

Artikel diterima: 20-02-2019, direvisi: 26-05-2019, diterbitkan: 31-05-2019

\begin{abstract}
Abstrak
Pemahaman konsep matematika masih rendah di kalangan pelajar baik pada tingkat dasar maupun menengah. Penggunaan pendekatan pembelajaran harus menjadi perhatian utama untuk memperoleh pemahaman konsep yang baik. Pendekatan Matematika Realistik (PMR) dapat dijadikan sebagai solusi dalam pembelajaran matematika. Penelitian ini untuk mengetahui apakah pemahaman konsep matematika siswa yang diajarkan dengan menggunakan PMR lebih baik dibandingkan dengan pemahaman konsep matematika yang diajarkan dengan menggunakan pendekatan konvensional. Penelitian ini merupakan penelitian eksperimen semu dengan desain penelitian Posttest-Only Group Control Design. Populasi dalam penelitian ini adalah seluruh siswa kelas VIII SMP Widya Bhakti Ruteng yang berjumlah 95 orang. Pengambilan sampel kelas dilakukan menggunakan teknik random sampling yang diawali dengan pengujian kesetaraan kelas. Data dikumpulkan dengan menggunakan instrumen yang berbentuk uraian dan menggunakan teknik tes. Hasil penelitian menunjukkan bahwa pemahaman konsep matematika siswa yang diajarkan dengan menggunakan pendekatan matematika realistik lebih baik dari siswa yang menggunakan pendekatan konvensional. Penggunaan pendekatan matematika realistik pada pembelajaran matematika berpengaruh terhadap pemahaman konsep siswa.

Kata Kunci: Pemahaman Konsep, Pembelajaran Konvensional, PMR
\end{abstract}

\section{Effect of Realistic Mathematical Approaches on Understanding Students' Mathematical Concepts}

\begin{abstract}
Understanding the concept of mathematics is still low among students both at the elementary and secondary levels. The use of a learning approach must be a major concern to obtain a good understanding of concepts. Realistic Mathematics Approach (PMR) can be used as a solution to teaching mathematics. This study is to find out whether understanding the mathematical concepts of students taught by using PMR is better than understanding mathematical concepts taught using the conventional approach. This research is a quasiexperimental study with research design Posttest-Only group Control Design. The population in this study were all eighth-grade students of Widya Bhakti Ruteng Middle School, totaling 95 people. Class sampling is done using a random sampling technique that begins with class equality testing. Data was collected using instruments in the form of descriptions and using test techniques. The results of the study indicate that understanding students' mathematical concepts taught using realistic mathematical approaches is better than students who use conventional approaches. The use of realistic mathematical approaches to learning mathematics influences the understanding of students' concepts.

Keywords: Understanding of Concepts, Conventional Learning, PMR.
\end{abstract}




\section{Pendahuluan}

Perkembangan ilmu pengetahuan dan teknologi (IPTEK) saat ini semakin masif. Atas situasi ini, manusia dituntut mampu adaptif yang ditunjang oleh kemampuan untuk berpikir secara kritis serta kooperatif (bekerja sama). Dengan kemampuan ini berbagai macam informasi yang bergerak begitu cepat dari berbagai sumber dapat disaring dan dimanfaatkan dengan baik untuk kebutuhan hidup (Yahaya \& Salam, 2014). Kemampuankemampuan ini diharapkan dimiliki oleh manusia khususnya generasi yang lahir pada era teknologi ini.

Kemampuan-kemampuan yang disebutkan di atas perlu dikembangkan. Salah satu jembatan yang dapat mencapai tujuan tersebut ialah melalui penguasaan ilmu matematika. Karakteristik ilmu matematika yang hierarkis, terstruktur, logis, dan sistematis akan memungkinkan siswa untuk terampil berpikir secara rasional (Husnaeni, 2016; Kurniati, Prahmana, Makur, \& Jelatu, 2018; Zulnaidi \& Zakaria, 2012).

Matematika berperan penting dalam berbagai disiplin dan memajukan daya pikir manusia (Nunes \& Bryant, 2000). Selain itu, matematika itu ibarat pohon beringin yang bercabang-cabang, namun bukan seperti pohon palem (Jelatu, Sariyasa, \& Ardana, 2018). Sangat tidak tepat apabila matematika dikatakan hidup untuk dirinya sendiri, tetapi matematika memiliki peran yang universal untuk ilmu yang lain maupun dalam perkembangan teknologi modern (Nunes \& Bryant, 2000).
Lebih lanjut Firdaus, Kailani, Bakar, Bin, dan Bakry (2015) menegaskan bahwa matematika sebagai salah satu disiplin ilmu berkontribusi dalam pengembangan IPTEK, solutif dalam persoalan kehidupan, serta membekali kemampuan berpikir dan berargumentasi.

Pendidikian merupakan wadah untuk mampu menguasai ilmu matematika. Hal ini ditandai oleh proses pembelajarannya. Pemerintah melalui Permendiknas tentang standar isi merumuskan bahwa salah satu tujuan belajar matematika di sekolah yaitu penguasaan terhadap konsep matematika (Jelatu, Mandur, Jundu, \& Kurniawan, 2018). Permendiknas tersebut menguraikan beberapa poin urgen yang mencirikan kemampuan memahami konsep matematika, yakni: menjelaskan keterkaitan antarkonsep dan mengaplikasikan konsep atau algoritma, secara luwes, akurat, efisien, dan tepat, dalam pemecahan masalah. Zulnaidi dan Zakaria (2012) menambahkan bahwa pemahaman konsep matematika merupakan akar atau dasar menuju penguasaan konsep matematika lainnya yang lebih tinggi atau serta menunjang kemampuan koneksi antara konsep tersebut.

Hadi dan Kasum (2015) menegaskan bahwa landasan penting yang digunakan untuk berpikir dalam menyelesaikan permasalahan matematika maupun permasalahan nyata yang relevan dengan matematika adalah pemahaman konsep matematika. Apabila pebelajar memiliki konseptualisasi yang baik, maka dapat 
dipastikan bahwa mereka akan mampu merekam, memahami, serta dapat mengaplikasikan, dan memodifikasi suatu konsep dalam menyelesaikan berbagai variasi permasalahan serta soal matematika (Lisnani, 2019; NCTM, 2000).

Namun, kepemilikan pemahaman konsep matematika yang baik belum sepenuhnya sampai pada seluruh pebelajar saat ini. Beberapa fakta di sekolah yang secara khusus ditemukan peneliti menunjukkan bahwa kondisi ideal yang diharapkan tentang pemahaman konsep masih kurang. Beberapa siswa masih menganggap matematika sulit dan tak bermakna. Mereka memiliki pandangan bahwa matematika banyak bergelut dengan perhitungan yang sulit dan rumus yang memerlukan daya ingat serta daya analisis dalam penggunaannya. Hal ini diketahui dari hasil wawancara tidak terstruktur dengan beberapa siswa. Kondisi ini menurut peneliti disebabkan oleh kecendrungan menghafal dan kurang melakukan perkenalan dengan apa yang mendasari atau apa kegunaan dari materi matematika yang dipelajari.

Setelah melakukan UTS dan UAS kepada siswa SMP Widya Bhakti Ruteng, serta pemberian beberapa soal yang berorientasi pengukuran pemahaman konsep, peneliti mendapatkan informasi bahwa dari tiga rombongan belajar yang berjumlah 95 orang, sebanyak 43 orang yang nilainya memenuhi kriteria ketuntasan minimal. Artinya, 60\% siswa yang tidak memenuhi kriteria ketuntasan minimal. Selain itu, hampir $70 \%$ persen siswa tidak mampu mengerjakan soal yang beorientasi pemahaman konsep. Informasi rendahnya prestasi belajar matematika memberikan gambaran tentang rendahnya pemahaman konsep matematika. Hal ini relevan dengan penelitian Hutagalung (2017) yang menemukan ada hubungan kausalitas antara rendahnya pemahaman konsep matematika siswa dan rendahnya pretasi belajar siswa.

Beberapa studi, menuturkan bahwa proses pembelajaran konvensional seperti pembelajaran yang berpusat pada guru kurang efektif dalam mencapai pemahaman konsep yang optimal. Fakta yang peneliti temukan membenarkan argumentasi ini. Oleh karena peran guru merupakan aspek sentral untuk mencapai tujuan pemahaman konsep, maka dalam konteks pembelajaran matematika yang kekinian, guru mesti berpandangan bahwa materi-materi matematika bukanlah sebuah materi hafalan, namun lebih dari itu, yaitu memahami konsep dari apa diberikan (Jehadus, 2018; Mueller, Yankelewitz, \& Maher, 2014). Dalam mempelajari matematika, siswa harus mampu memahami konsep yang melandasi matematika atau materi yang diajarkan. Hal ini direfleksikan melalui pemisalan dimana siswa mampu mendefenisikan kembali bahan pelajaran matematika dengan bahasa mereka sendiri, mampu mengklasifikasikan contoh serta bukan contoh. Kedua kata kerja operasional ini menggambarkan bahwa konsep matematika bukan hanya sekedar dihafal.

\section{Mosharafa: Jumal Pendidikan Matematika}


Salah satu pembelajaran yang mampu mengakomodasi siswa dalam mengembangkan pemahaman konsep matematika yaitu pembelajaran matematika realistik (PMR) (Fitriani \& Maulana, 2016). PMR adalah salah satu pendekatan pembelajaran yang pertama kali dikembangkan oleh sekelompok ahli matematika dari freudenthal institute, Utrecht University di Negeri Belanda pada tahun 1971 (Afriansyah, 2016; Muhtadi \& Sukirwan, 2017; Sugihatno, Budiyono, \& Slamet, 2017). PMR berpandangan bahwa matematika adalah kegiatan manusia. Eksplorasi ide, konsep, masalah nyata merupakan aktifitas kelas matematika (Soviawati, 2011). Oleh karena matematika merupakan aktifitas manusia, maka PMR berorientasi pada relevansi antara konsep matematika dengan konteks permasalahan di dunia nyata dan juga berorientasi pada siswa (Wardono \& Mariani, 2018; Warsito, Nuraini, \& Sukirwan, 2019).

PMR merupakan pendekatan yang bermula pada permasalahan yang nyata bagi siswa, mengutamakan keterampilan proses (process of doing mathematics), diskusi dan kolaborasi, interaktif (tutor sebaya) dengan maksud agar mereka berkekuatan penuh untuk bereksperimen baik secara individu maupun kelompok (Ahmad \& Asmaidah, 2017; Sirait \& Azis, 2017). Dalam PMR, guru berperan dalam menfasilitasi proses belajar untuk memungkinkan terjadinya interaksi yang optimal serta menerapkan scaffolding (Özkaya \& Karaca, 2017). 194
Tujuan dari PMR adalah memberikan kesempatan kepada siswa untuk menemukan kembali dan merekonstruksi konsep-konsep matematika dengan mengaitkan konsep-konsep matematika dengan dunia nyata, sehingga siswa mempunyai pengertian yang kuat tentang konsep-konsep matematika. PMR akan secara operasional memberikan pengertian tentang relevansi serta kegunaan matematika (materi yang diajarkan) dengan dan atau dalam kehidupan sehari-hari. Semua kajian tersebut akan secara independen dikonstruksi dan dikembangkan oleh siswa. Selain itu, penyelesaian masalah tidak harus tunggal dan tidak harus sama antara satu siswa dengan siswa lainnya. Beberapa penelitian terdahulu menunjukan bahwa PMR efektif dalam meningkatkan kemampuan matematis siswa (Ahmad \& Asmaidah, 2017; Alamiah \& Afriansyah, 2017; Lisnani, 2019; Muhtadi \& Sukirwan, 2017)

Berdasarkan uraian-uraian di atas, maka peneliti bertujuan untuk membuktikan secara empirik dan ilmiah tentang pengaruh pendekatan matematika realistik terhadap pemahaman konsep matematis siswa.

\section{Metode}

Jenis penelitian adalah penelitian eksperimen semu. Penelitian ini menggunakan Posttest-Only Control Grup Design. Terdapat dua kelompok yang terlibat dalam peneltian ini yakni kelompok yang mendapat perlakuan Mosharafa: Jurnal Pendidikan Matematika Volume 8, Nomor 2, Mei 2019 Copyright $\odot 2019$ Mosharafa: Jurnal Pendidikan Matematika 
(eksperimen) dan kelompok yang tidak mendapat perlakuan (kontrol). Kedua kelompok yang terlibat dalam penelitian ini dipilih secara random (random kelas). Adapun kelompok eksperimen yaitu kelompok yang dalam proses pembelajaran menggunakan Pendekatan Matematika Realistik (PMR) dan kelompok yang dalam proses pembelajaran menggunakan pendekatan konvensional adalah kelompok kontrol.

Populasi dalam penelitian ini adalah seluruh siswa kelas VIII SMP Widya Bhakti Ruteng tahun ajaran 2018/2019. Dalam penelitian ini, peneliti mengambil dua kelas yang dijadikan sebagai kelas kontrol dan kelas eksperimen. Dalam pelaksanaannya, peneliti melakukan random sampling. Sebelum dilakukan random sampling dilakukan uji kesetaraan kelas. Dari proses tersebut diperoleh hasil bahwa kelas VIII C terpilih sebagai kelas eksperimen sedangkan kelas VIII A sebagai kelas kontrol.

Teknik pengumpulan data yang digunakan adalah tes. Tes diberikan saat peneliti telah melakukan treatment untuk mengukur ketercapaian siswa pada aspek pemahaman konsep matematika.

Data yang diperoleh dalam penelitian ini dianalisis dengan menggunakan teknik statistik deskriptif dan inferensial (Uji-t). Statistik inferensial (uji-t) digunakan untuk menguji perbedaan rerata pemahaman konsep matematis siswa antara kelas eksperimen dan kelas kontrol. Persyaratan pengujian hipotesis adalah data terlebih dahulu dilakukan pengujian populasi

\section{Mosharafa: Jurnal Pendidikan Matematika}

Volume 8, Nomor 2, Mei 2019

Copyright @ 2019 Mosharafa: Jurnal Pendidikan Matematika dengan menggunakan uji normalitas dan uji homogenitas.

\section{Hasil dan Pembahasan}

Data dalam penelitian ini diperoleh dari hasil posttest yang diberikan setelah kelas eksperimen dan kelas kontrol mendapatkan perlakuan. Deskriptif data mencakup perhitungan nilai mean, median, modus, varians dan standar deviasi. Dalam penelitian ini, statistik deskriptif data dihitung dengan bantuan SPSS versi 16.0. Adapun statistik deskriptif data posttest dari penelitian ini baik kelas eksperimen maupun kelas kontrol dapat disajikan pada tabel berikut.

Dari tabel 1, terlihat bahwa kelas eksperimen mempunyai rentangan nilai dari 51 sampai dengan 80, nilai rata-rata sebesar 65,26, median 67, modus 64, varians 64, dan standar deviasi 7,94 sedangkan pada kelas kontro Imempunyai rentangan nilai dari 44 sampai dengan 73, nilai rata-rata sebesar 60,55 , median 65 , modus 65, varians 62,16, dan standar deviasi 7,92.

Data frekuensi nilai posttest kelas Tabel 1

Deskripsi Data Kelas Posttest

\begin{tabular}{|lcc|}
\hline \multicolumn{1}{c}{ Statistika } & \multicolumn{2}{c}{ Kelas } \\
\cline { 2 - 3 } \multicolumn{1}{c}{} & Eksp. & Kontrol \\
\hline Jumlah Siswa & 33 & 31 \\
\hline Maksimum (Xmaks) & 80 & 73 \\
\hline Minimum (Xmin) & 51 & 44 \\
\hline Rata-rata & 65,26 & 60.55 \\
\hline Median (Me) & 67 & 65 \\
\hline Modus (Mo) & 64 & 65 \\
\hline Varians & 63,97 & 62,16 \\
\hline Standar Deviasi (S) & 7.94 & 7,92 \\
\hline
\end{tabular}


eksperimen dan kelas kontrol dapat dilihat pada gambar 1.

Dari data yang disajikan pada gambar 1 menunjukkan adanya perbedaan perhitungan antara dua kelas. Secara statistik deskriptif diperoleh bahwa nilai rata-rata kelas eksperimen lebih tinggi dari pada nilai rata-rata pada kelas kontrol dengan selisih 4,71.

Sebelum melakukan analisis data terlebih dahulu dilakukan uji prasyarat analisis yakni uji normalitas dan homogenitas. Apabila uji prasyarat analisis terpenuhi maka data akan dianalisis menggunakan statistik parametris, namun apabila uji prasyarat analisis tidak terpenuhi maka statistik yang digunakan untuk menganalisis data adalah statistik nonparametris.

Uji normalitas data pada penelitian ini bertujuan untuk mengetahui apakah data sampel berasal dari populasi yang berdistribusi normal atau tidak (lihat tabel 2).

Berdasarkan data pada tabel 2 terlihat bahwa nilai signifikan pada kelas

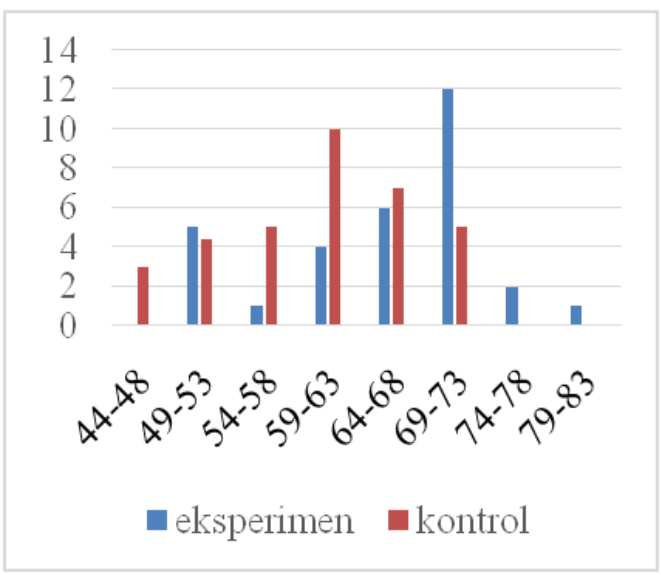

Gambar 1. Diagram Batang Hasil Posttest eksperimen yakni 0,147 dan pada kelas kontrol 0,086. Kedua nilai ini $\geq 0,05$, sehingga dapat disimpulkan kedua kelas tersebut berdistribusi normal.

Uji homogenitas adalah uji untuk mengetahui apakah kedua kelompok sampel berasal dari populasi yang tidak jauh berbeda dari keseragamannya. Adapun ketentuan dalam pengujian homogenitas adalah jika sig. > 0.05 maka data homogen. Berikut ditampilkan tabel mengenai hasil uji homogenitas data berupa nilai posttest kelas eksperimen dan kelas kontrol.

Data pada tabel 3 menujukan bahwa nilai siginifikansi $0,065 \geq 0,05$. Artinya, data Posttest kelas eksperimen dan kelas kontrol berasal dari populasi yang homogen.

Berdasarkan uraian sebelumnya terlihat bahwa uji prasyarat analisis data telah terpenuhi. Hasil perhitungan menunjukkan data berupa nilai hasil posttest kelas eksperimen dan kelas kontrol berdistribusi normal dan homogen. Karena uji prasyarat analisis data telah terpenuhi, selanjutnya

Tabel 2

Hasil Uji Normalitas Data

\begin{tabular}{|ccccccc|}
\hline \multicolumn{6}{c}{ Kolmogorov-Smirnov $^{\text {a }}$} & \multicolumn{4}{c}{ Shapiro-Wilk } \\
\hline & Stat. & Df & Sig. & Stat. & Df & Sig. \\
\hline$R_{1}$ & .144 & 31 & .102 & .949 & 31 & .147 \\
\hline$R_{2}$ & .128 & 33 & .187 & .944 & 33 & .086
\end{tabular}

Tabel 3

Uji Homogenitas Data dengan SPSS

\begin{tabular}{|cccc|}
\hline Levene & & & \\
\cline { 2 - 4 } Statistic & $\mathrm{df1}$ & $\mathrm{df2}$ & Sig. \\
\hline .270 & 1 & 62 & .605 \\
\hline
\end{tabular}


dilakukan proses analisis data berupa pengujian hipotesis. Pengujian hipotesis dilakukan menggunakan statistik parametris berupa uji-t. Rumus uji-t yang digunakan dalam penelitian ini adalah $t$ test polled varian. Adapun hipotesis yang diuji dalam penelitian ini adalah:

$\mathrm{H}_{0}$ : Pemahaman konsep matematis siswa yang diajarkan dengan PMR tidak lebih baik dari pemahaman konsep siswa yang diajarkan dengan model pembelajaran langsung.

$\mathrm{H}_{\mathbf{1}}$ : Pemahaman konsep matematis siswa yang diajarkan dengan PMR lebih baik dari pemahaman konsep siswa yang diajarkan dengan model pembelajaran langsung.

Berdasarkan hipotesis penelitian tersebut, maka dapat dirumuskan hipotesis statistik sebagai berikut:

$$
\begin{aligned}
& \mathrm{H}_{0}: \mu_{1} \leq \mu_{2} \\
& \mathrm{H}_{1}: \mu_{1}>\mu_{2}
\end{aligned}
$$

Keterangan:

$\mu_{1}$ : Rata-rata skor pemahaman konsep siswa pada kelompok eksperimen.

$\mu_{2}$ : Rata-rata skor pemahaman konsep siswa pada kelompok kontrol.

Dari hasil analisis diketahui bahwa nilai signifikan sebesar 0,018 . Nilai sig. $\leq$ 0,05 maka $H_{0}$ ditolak dan $H_{1}$ diterima. Hasil ini menggambarkan pemahaman konsep siswa yang diajarkan dengan PMR lebih baik dibandingkan dengan pemahaman konsep siswa yang diajarkan dengan pembelajaran langsung. Dari hasil pengujian hipotesis yang telah dilakukan dapat disimpulkan bahwa PMR memberikan berpengaruh yang positif terhadap perolehan pemahaman konsep matematika siswa.

Penelitian ini dilaksanakan di SMP Widya Bhakti Ruteng. Dalam penelitian ini materi pembelajaran yang diajarkan pada kelas eksperimen dan kelas kontrol adalah sistem persamaan linear dua variabel, masing-masing dalam kurun waktu $12 \times 45$ menit atau 6 kali pertemuan tatap muka.

Berdasarkan data hasil penelitian yang telah dideskripsikan, hasil perolehan data posttest menunjukkan bahwa skor maksimum dan minimum kelas eksperimen lebih tinggi dari skror maksimum dan minimum kelas kontrol, nilai rata-rata pemahaman konsep matematis siswa pada kelas eksperimen yaitu 65,26 dan pada kelas kontrol 60.55, Selanjutnya dari hasil uji hipotesis menujukan bahwa $H_{0}$ ditolak dan $H_{1}$ diterima. Hal ini berarti rata-rata skor pemahaman konsep matematis siswa yang menggunakan PMR lebih baik dari ratarata skor pemahaman konsep matematika siswa yang menggunakan pembelajaran langsung.

Perbedaan hasil kedua kelas tersebut disebabkan oleh perbedaan orientasi pada aktifitas pembelajaran yang menunjukan bahwa PMR lebih mengedepankan kegiatan siswa. Aktifitas ini direfleksikan melalui kegiatan menemukan, mengolah, dan melaporkan informasi yang diperoleh melalui beragam sumber, serta melakukan presentasi hasil kerja (Afriansyah, 2017; Nopiyani, Turmudi, \& Prabawanto, 2016; Widyastuti \& Pujiastuti, 2014). 
Temuan dalam penelitian ini sejalan dengan penelitian yang dilakukan oleh Özkaya \& Karaca (2017), Putra (2016), dan Widyastuti \& Pujiastuti (2014) yang menunjukkan bahwa kemampuan matematika siswa yang mengikuti pembelajaran matematika realistik lebih tinggi dari kemampuan matematis siswa yang mengikuti pembelajaran konvensional. Salah satu kemampuan tersebut adalah pemahaman konsep. Dengan demikian, ada pengaruh penerapan pembelajaran matematika realistik terhadap pemahaman konsep matematika siswa.

Pada PMR, aktifitas pembelajaran diawali dengan menggali pengalamanpengalaman siswa dalam kesehariaanya (masalah yang kontekstual). Hal ini akan memungkinkan siswa menggunakan pengalaman atau pengetahuan yang telah dimiliki sebelumnya untuk menyelesaikan serta memahami kegunaan dari materi yang diajarkan (Sirait \& Azis, 2017). Tahap kedua yaitu use models (penggunaan model). Pada tahap ini, terlibat dalam aktifitas menemukan secara aktif berbagai ide atau gagasan dari situasi yang sebenarnya. Model tersebut berfungi sebagai petunjuk atau pengarah untuk mencapai pemahaman tentang model yang lebih formal (Zakaria \& Syamaun, 2017).

Pada tahap ketiga yaitu students' contribution (konstribusi siswa). Pada tahap ini lingkungan belajar berorientasi pada siswa. Siswa berkesempatan untuk mengekspresikan berbagai strategi untuk 198 bereksperimen menemukan konsep serta mengkonstruksi berbagai prosedur untuk memecahkan masalah. Siswa diharapkan menampilkan seluruh konstribusinya serta membatasi ruang otoritarian seorang guru. Kemudian pada tahap keempat terjadi interaktivitas (interactivity) antara siswa dengan guru serta siswa dengan siswa. Melalui interaksi ini siswa akan memperoleh pembenaran, klarifikasi, serta proyeksi terkait temuan-temuan. Selain itu, mereka juga melakukan refleksi untuk mencapai bentuk yang formal dari temuan secara yang dilakukan secara independen oleh siswa. Pada tahap kelima atau tahap penutup siswa diminta untuk mengintegrasikan materi yang mereka dapat dengan topik lainnya (intertwining).

Pada kelas yang menggunakan pembelajaran konvensional, aktifitas eksplorasi oleh siswa tidak nampak. Guru sebagai pemberi ilmu melakukan desain lingkungan belajar yang memungkinkan adanya kekuatan ingatan. Siswa cenderung menunjukan perilaku pasif dan hanya mengikuti segala petunjuk atau informasi dari sumber ilmu, baik berupa tulisan maupun lisan. Ekspresi ketidakpahaman siswa tampak saat guru melakukan audience tentang materi yang telah diceramahkan. Sebagian kecil siswa yang ikut bertanya, sedangkan siswa yang lain hanya terlihat diam. Hanya beberapa siswa yang aktif dan berani untuk mengerjakan soal latihan yang diberikan di depan kelas. Pembelajaran di kelas terasa monoton dan kurang menyenangkan. Guru hanya menyampaikan materi tahap demi tahap Mosharafa: Jurmal Pendidikan Matematika Volume 8, Nomor 2, Mei 2019 Copyright $\odot 2019$ Mosharafa: Jurnal Pendidikan Matematika 
dan siswa diberikan kesempatan untuk mencatat dan diberikan soal latihan. Siswa juga terlihat kurang bersemangat saat mengerjakan soal latihan yang diberikan, mereka cenderung menunggu jawaban dari teman yang lebih pintar ataupun penjelasan lanjutan dari guru. Hal seperti inilah yang membuat siswa sulit untuk memahami konsep dari materi yang telah diberikan, sehingga pemahaman konsep matematis siswa cukup rendah.

Berdasarkan pembahasan di atas dapat disimpulkan bahwa penggunaan pendekatan matematika realistik pada pembelajaran matematika berpengaruh terhadap pemahaman konsep siswa. Hal ini berarti siswa yang mengikuti pembelajaran dengan pendekatan matematika realistik di kelas lebih baik dalam memahami konsep matematis dibandingkan siswa yang mengikuti pembelajaran langsung.

\section{Penutup}

Berdasarkan hasil penelitian dan pembahasan dapat dibuat kesimpulan bahwa penggunaan PMR dalam pembelajaran matematika pada pokok bahasan sistem persamaan linear dua variabel berpengaruh positif terhadap pemahaman konsep matematika siswa. Untuk itu, sebagai bentuk implikasi, maka diharapkan para guru dapat mengimplementasikan PMR dalam proses pembelajaran matematika. Selain sebagai penunjang ketercapaian pemahaman konsep matematika, PMR dapat membangkitkan semangat siswa dalam belajar. Keterlibatan penuh siswa dalam
PMR dapat memberikan dampak positif bagi pemahaman terbentuknya sikap tanggung jawab serta kerja keras dari siswa. Dengan menggunakan PMR dalam proses pembelajaran matematika, setiap siswa memiliki persiapan yang baik, tidak takut dalam mengungkapkan pendapat atau ide serta bertanggung jawab.

Berikut beberapa saran yang dapat disampaikan peneliti terkait penelitian ini. (1) Guru hendaknya menerapkan pendekatan matematika realistic sebagai pembelajaran yang mampu mengaktifkan siswa dan meningkatkan kerja sama siswa dalam menyelesaikan permasalahan matematika sebagai upaya meningkatkan kemampuan pemahaman konsep matematika siswa. (2) Para peneliti untuk melakukan penelitian lanjutan dengan mengkaji faktor-faktor lain yang mempengaruhi kemampuan pemahaman konsep matematika sehingga menambah wawasan yang lebih luas. (3) Diharapkan kepada pihak sekolah agar dapat memfasilitasi sehingga penggunaan pendekatan pembelajaran pada setiap proses pembelajaran berjalan dengan baik.

\section{UCAPAN TERIMA KASIH}

Ucapan terima kasih penulis haturkan kepada pihak sekolah yang telah mengijinkan penulis untuk melakukan penelitian.

\section{DAFTAR PUSTAKA}

Afriansyah, E. A. (2016). Makna Realistic dalam RME dan PMRI. LEMMA, //(2), 96-104. 
https://doi.org/10.22202/jl.2016.v2i2 .578

Afriansyah, E. A. (2017). Desain Lintasan Pembelajaran Pecahan Melalui Pendekatan Realistic Mathematics Education. Mosharafa: Jurnal Pendidikan Matematika, 6(3), 463474.

Ahmad, M., \& Asmaidah, S. (2017). Pengembangan Perangkat Pembelajaran Matematika Realistik untuk Membelajarkan Kemampuan Pemecahan Masalah Matematika Siswa SMP. Mosharafa: Jurnal Pendidikan Matematika, 6(3), 373384.

Alamiah, U. S., \& Afriansyah, E. A. (2017). Perbandingan Kemampuan Komunikasi Matematis Siswa antara yang Mendapatkan Model Pembelajaran Problem Based Learning dengan Pendekatan Realistic Mathematics Education dan OpenEnded. Mosharafa: Jurnal Pendidikan Matematika, 6(2), 207-216.

Firdaus, F., Kailani, I., Bakar, M. N. Bin, \& Bakry, B. (2015). Developing Critical Thinking Skills of Students in Mathematics Learning. Journal of Education and Learning (EduLearn), 9(3), 226.

Fitriani, K., \& Maulana. (2016). Meningkatkan Kemampuan Pemahaman dan Pemecahan Masalah Matematis Siswa SD Kelas V melalui Pendekatan Matematika Realistik. Mimbar Sekolah Dasar, 3(1), 40-52.

https://doi.org/10.17509/mimbarsd.v3i1.2355

Hadi, S., \& Kasum, M. U. (2015). Pemahaman konsep matematika siswa smp melalui penerapan model pembelajaran kooperatif tipe memeriksa berpasangan (pair checks). EDU-MAT Jurnal Pendidikan Matematika, 3(April), 59-66.

Husnaeni. (2016). The Enhancement of Mathematical Critical Thinking Ability of Aliyah Madrasas Student Model Using Gorontalo by Interactive Learning Setting Cooperative Model. Journal of Education and Practice, 7(8), 159-164.

Hutagalung, R. (2017). Peningkatan kemampuan pemahaman konsep matematis siswa melalui pembelajaran guided discovery berbasis budaya toba di smp negeri 1tukka. MES (Journal of Mathematics Education and Science), 2(2), 70-77.

Jehadus, E. (2018). Model Quantum Untuk Mengatasi Kecemasan. Jurnal Pendidikan Dan Kebudayaan Missio, 10(2), 137-142.

Jelatu, S., Mandur, K., Jundu, R., \& Kurniawan, Y. (2018). Relasi Antara Visualisasi Spasial dan Orientasi Spasial terhadap Pemahaman Konsep Geometri Ruang. Journal of Songke Math, 1(1), 47-59.

Jelatu, S., Sariyasa, S., \& Ardana, I. M. (2018). Effect of GeoGebra-Aided REACT Strategy on Understanding of Geometry Concepts. International Journal of Instruction, 11(4), 325336.

https://doi.org/10.12973/iji.2018.114 $21 \mathrm{a}$

Kurniati, K., Prahmana, R. C. I., Makur, A. P., \& Jelatu, S. (2018). Math Comics, Vectors, and the Strategy of Preview, Question, Read, Reflect, Recite, Review (PQ4R). Formatif: Jurnal IImiah Pendidikan MIPA, 8(3), 159174. 
https://doi.org/10.30998/formatif.v8i 3.2716

Lisnani, L. (2019). Pemahaman Konsep Awal Calon Guru Sekolah Dasar Tentang Pecahan. Mosharafa: Jurnal Pendidikan Matematika, 8(1), 61-70. https://doi.org/10.31980/mosharafa. v8i1.388

Mueller, M., Yankelewitz, D., \& Maher, C. (2014). Teachers Promoting Student Mathematical Reasoning. Investigations in Mathematics Learning, 7(2), 1-20. https://doi.org/10.1080/24727466.20 14.11790339

Muhtadi, D., \& Sukirwan. (2017). Implementasi Pendidikan Matematika Realistik (PMR) untuk Meningkatkan Kemampuan Berpikir Kreatif Matematik dan Kemandirian Belajar Peserta Didik. Mosharafa: Jurnal Pendidikan Matematika, 6(1), 1-12.

NCTM. (2000). Principles and Standards for School Mathematics. VA: NCTM.

Nopiyani, D., Turmudi, \& Prabawanto, S. (2016). Penerapan Pembelajaran Matematika Realistik Berbantuan GeoGebra untuk Meningkatkan Kemampuan Komunikasi Matematis Siswa SMP. Mosharafa: Jurnal Pendidikan Matematika, 5(2), 45-52.

Nunes, T., \& Bryant, P. (2000). Learning and Teaching Mathematics, An International Perspective. UK: Psychology Press.

Özkaya, A., \& Karaca, S. Y. (2017). the Effects of Realistic Mathematics Education on Students , Achievements and Attitudes in Fifth Grades Mathematics Courses. International Online Journal of Education and Teaching (IOJET), 4(2), 185-197.
Putra, F. G. (2016). Pengaruh Model Pembelajaran Reflektif dengan Pendekatan Matematika Realistik Bernuansa Kelslaman Terhadap Kemampuan Komunikasi Matematis Peserta Didik. Al-Jabar: Jurnal Pendidikan Matematika, 7(2), 105116.

Sirait, A. R., \& Azis, Z. (2017). The Realistic of Mathematic Educational Approach (RME) toward the Ability of the Mathematic Connection of Junior High School in Bukhari Muslim Medan. American Journal of Educational Research, 5(9), 984-989. https://doi.org/10.12691/education5-9-10

Soviawati, E. (2011). Pendekatan Matematika Realistik (PMR) untuk Meningkatkan Kemampuan Berfikir Siswa di Tingkat Sekolah Dasar. Jurnal Penelitian Pendidikan, Edisi Khus(2), 79-85.

Sugihatno, A. C. M. S., Budiyono, \& Slamet, I. (2017). Realistic Matematic Approach through Numbered Head Together Learning Model. Journal of Physics: Conference Series, 895(1), 012026.

https://doi.org/10.1088/1742-

6596/895/1/012026

Wardono, \& Mariani, S. (2018). The analysis of mathematics literacy on PMRI learning with media schoology of junior high school students. Journal of Physics: Conference Series, 983(1), 012107. https://doi.org/10.1088/17426596/983/1/012107

Warsito, W., Nuraini, Y., \& Sukirwan, S. (2019). Desain Pembelajaran Pecahan melalui Pendekatan Realistik di Kelas V. Mosharafa: Jurnal Pendidikan 
Matematika, 8(1), 25-36.

Widyastuti, N. S., \& Pujiastuti, P. (2014). Pengaruh Pendidikan Matematika Realistik Indonesia (PMRI) Terhadap Pemahaman Konsep dan Berpikir Logis Siswa. Jurnal Prima Edukasia, 2(2),

https://doi.org/10.21831/jpe.v2i2.27 18

Yahaya, N. S., \& Salam, S. N. A. (2014). Mobile Learning Application for Children: Belajar Bersama Dino. Procedia - Social and Behavioral Sciences, 155(October), 398-404.

Zakaria, E., \& Syamaun, M. (2017). The Effect of Realistic Mathematics Education Approach on Students' Achievement And Attitudes Towards Mathematics.

Mathematics Education Trends and Research, 2017(1), 32-40. https://doi.org/10.5899/2017/metr00093

Zulnaidi, H., \& Zakaria, E. (2012). The Effect of Using GeoGebra on Conceptual and Procedural Knowledge of High School Mathematics Students. Asian Social Science, 8(11), 102-106. https://doi.org/10.5539/ass.v8n11p1

02

\section{Riwayat Hidup PenUlis}

\section{Adrianus Akuila Jeheman, S.Pd.}

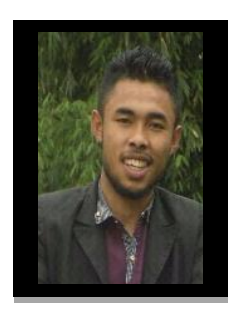

Lahir di Borong, Kab. Manggrai Timur, NTT, pada tanggal 08 Juli 1996. Studi S1 Pendidikan Matematika di Sekolah Tinggi Keguruan dan Ilmu Pendidikan (STKIP) Santu Paulus Ruteng, Lulusan tahun 2018

\section{Bedilius Gunur, M.Pd.}

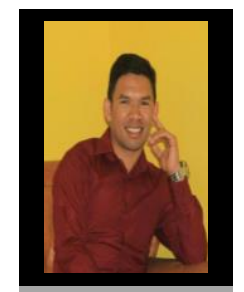

Lahir di Ajang Desa Bangka Ajang Kecamatan Rahong Utara Kabupaten Manggarai pada tanggal o9 September 1988. Sejak 2012 sampai sekarang menjadi staf pengajar di STKIP Santu Paulus Ruteng. Studi S1 bidang Pendidikan Matematika tahun 2008 di Universitas Cokroaminoto Palopo dan tamat pada Tahun 2012. Studi S2 bidang Pendidikan Matematika tahun 2014 di Universitas Ganesha Singaraja Denpasar dan tamat pada Tahun 2016.

\section{Silfanus Jelatu, M.Pd.}

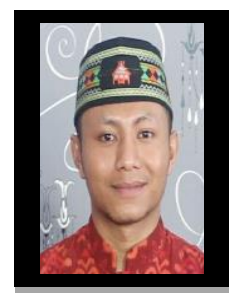

Lahir di Mukun (Kab. Manggarai Timur, NTT), pada tanggal 4 Mei 1992. Staf pengajar di Program Studi Pendidikan Matemaika STKIP Santu Paulus Ruteng. Studi S1 di bidang pendidikan matematika Universitas Flores, Ende-NTT, lulus tahun 2014; S2 di Bidang Pendidikan Matematika Universitas Pendidikan Ganesha, Singaraja-Bali, lulus tahun 2017; Beberapa publikasi telah dilakukan baik pada jurnal internasional bereputasi, jurnal nasional terakreditasi, maupun junrla yang tidak terakreditasi. Salah satu tulisan dengan judul "Effect of GeoGebra-Aided REACT Strategy on Understanding of Geometry Concepts" dipublikasikan pada jurnal internasional bereputasi (SCOPUS Q3) yaitu International Journal of Instruction pada tahun 2018. 